RESEARCH NOTE

\title{
Relationship between chloride concentration and electrical conductivity in groundwater and its estimation from vertical electrical soundings (VESs) in Guasave, Sinaloa, Mexico
}

\author{
Héctor Peinado-Guevara ${ }^{1,6}$, Carlos Green-Ruíz ${ }^{2}$, Jaime Herrera-Barrientos ${ }^{3}$, \\ Oscar Escolero-Fuentes ${ }^{1}$, Omar Delgado-Rodríguez ${ }^{4}$, Salvador Belmonte- \\ Jiménez ${ }^{5}$, and María Ladrón de Guevara ${ }^{5}$ \\ ${ }^{1}$ Instituto de Geología, Universidad Nacional Autónoma de México, Ciudad Universitaria, C.P. 04510, \\ México, D.F., México. \\ ${ }^{2}$ Instituto de Ciencias del Mar y Limnología, Universidad Nacional Autónoma de México, C.P. 82040, \\ Mazatlán, Sin. México \\ ${ }^{3}$ Centro de Investigación Científica y de Educación Superior de Ensenada (CICESE), Ensenada, C.P. 22860, \\ Ensenada, B.C. México. \\ ${ }^{4}$ Instituto Mexicano del Petróleo (IMP), C.P. 07730, Distrito Federal, México. \\ ${ }^{5}$ Centro Interdisciplinario de Investigación para el Desarrollo Integral Regional (CIIDIR), Unidad Oaxaca. \\ C.P. 71230 , Oaxaca, México. \\ ${ }^{6}$ Escuela de Ciencias Económicas y Administrativas (ECEA), Universidad Autónoma de Sinaloa, C.P. 81101, \\ Guasave, Sinaloa, México.
}

\begin{abstract}
H. Peinado-Guevara, C. Green-Ruíz, J. Herrera-Barrientos, O. Escolero-Fuentes, O. DelgadoRodríguez, S. Belmonte-Jiménez, and M. Ladrón de Guevara. 2012. Relationship between chloride concentration and electrical conductivity in groundwater and its estimation from vertical electrical soundings (VESs) in Guasave, Sinaloa, Mexico. Cien. Inv. Agr. 39(1): 229-239. Soils in arid or semi-arid areas often have salinity problems, so the quality of irrigation water plays an important role in agricultural production. Groundwater quality analysis includes the determination of chloride ions, which are toxic to plants in high concentrations. A total of 1358 groundwater samples were collected and analyzed in the period 1980-2008. Water electrical conductivity $[\mathrm{EC}]$ and chloride ion concentration values were related by the linear equation $\left[\mathrm{Cl}^{-}\right]=4.928 \mathrm{EC}(\mathrm{R}>0.94)$, to estimate the concentration of chloride ions as a function of the electrical conductivity of water in the study area. A geophysical survey was conducted through 34 Vertical Electrical Soundings (VESs) to calculate the water electrical conductivity from the interpretation of the apparent resistivity data. Twenty-nine VESs were used to relate the resistivity of the saturated formation (Ro) with that for the groundwater (Rw) by the linear equation $\mathrm{Rw}$ $=0.427$ Ro +1.987 . Then, EC was estimated as the inverse of Rw. Finally, the chloride ion concentration was determined by the equation mentioned above. Following the same procedure for the five remaining VESs, which were acquired in places where there are no wells, the chloride ion concentration and the electrical resistivity of the saturated formation (Ro) and groundwater (Rw and its inverse EC) were obtained without requiring a destructive technique.
\end{abstract}

Key words: Archie's Law, chlorides, electrical conductivity, resistivity, vertical electrical sounding (VES).

Received June 13, 2010. Accepted July 7, 2011.

Corresponding author: hpeinado75@hotmail.com 


\section{Introduction}

In saline soils, excess ions frequently include chlorides, sulphates, bicarbonates, sodium, calcium and magnesium. The effects from the presence of all these ions on plant growth are generally evaluated by comparing the reaction of plants growing in isosmotic solutions of different salts. A generalization of the toxic effect of salts and ions is not possible due to the different responses among species and even among varieties of the same plant species (Richards, 1954).

Chlorides widely distributed in nature include sodium $(\mathrm{NaCl})$, potassium $(\mathrm{KCl})$ and calcium $\left(\mathrm{CaCl}_{2}\right)$ salts . In the United States, aquifers prone to seawater intrusion are characterized by chloride contents in concentrations between 5 and $460 \mathrm{mg} \mathrm{L}^{-1}$, whereas the average concentration in contaminated wells in the Philippines is $141 \mathrm{mg} \mathrm{L}^{-1}$. The levels of chloride in non-contaminated waters are frequently lower than $10 \mathrm{mg} \mathrm{L}^{-1}$ and sometimes lower than $1 \mathrm{mg} \mathrm{L}^{-1}$ (WHO, 2003). Chlorides are considered important in the nutritional balance of plants, and there is a frequent and remarkable lack of this chemical element. The effects of chlorides on the control of root and foliar diseases in some crops such as wheat and barley also benefit vegetal nutrition (Crovetto, 1999).

However, excessive chloride accumulation damages the leaves of fruit trees, such as avocado, almond, papaya, sapote, mango, cherimoya, vitis, walnut and citrus trees. The toxic level of chlorine accumulation in leaves is not yet well defined, as leaves showing burn damage may have a lower chlorine accumulation than leaves not showing it (Aceves, 1979). The degree of ion chloride restriction $\left(\mathrm{Cl}^{-}\right)$ in irrigation water with concentrations lower than 4 meq $\mathrm{L}^{-1}$ is considered light, between 4 and $10 \mathrm{meq}$ $\mathrm{L}^{-1}$ is moderate, and concentrations higher than 10 meq $\mathrm{L}^{-1}$ are considered severe. The maximum limit is $30 \mathrm{meq} \mathrm{L}^{-1}$ (Palacios et al., 1997).

Water electrical conductivity (EC) is usually used as a salinity indicator. The presence of dissolved salts in water is related to the value of its EC, as they provide electrical charges interacting as ions in movement. EC can be easily measured by a conductivity meter. The chloride concentration is normally measured by silver nitrate titration $\left(\mathrm{AgNO}_{3}\right)$, although this type of analysis is more expensive and takes longer than EC measurements.

Chloride ions are the main constituents in waters and saline soils that directly affect the EC values; therefore, it is possible to find a strong correlation between $\mathrm{EC}$ and $\mathrm{Cl}^{-}$concentrations, as found by many authors (Oteri, 1988; Hajrasuliha et al., 1991; Xu and Eckstein, 1997; McNeil and Cox, 2000; Abyaneh et al., 2005; Alhumoud et al., 2010). Hajrasuliha et al. (1991) found that the relation of the $\mathrm{Cl}^{-}$concentration in meq $\mathrm{L}^{-1}$ is approximately 6,83 times the $\mathrm{EC}$ for $\mathrm{EC}=28 \mathrm{dS} \mathrm{m}^{-1}$ and 5,22 for $\mathrm{EC}=16 \mathrm{dS} \mathrm{m}^{-1}$; in other words, the gradient increases as the EC value increases. However, Abyaneh et al. (2005) found that [Cl- $=9 \mathrm{EC}$ for an EC range of 0.15 and $39.9 \mathrm{dS} \mathrm{m}^{-1}$. Many studies have used the $\mathrm{Cl}^{-}$concentration in the underground water to define the degree of saline intrusion. Some authors state that a threshold of chloride concentration ranging between 40 and $300 \mathrm{mg} \mathrm{L}^{-1}$ is an indication of seawater invasion (Edet and Okereke, 2001).

Likewise, empirical relations between EC and soil and water salinity expressed in the same equation have been obtained (Reluy et al., 2004). Additionally, water electrical resistivity (inverse to EC) is related to the electrical resistivity of the saturated aquifer thickness (Ro), which may be estimated by electrical methods of geophysical prospecting through Vertical Electrical Soundings (VESs) (Keller and Frischknecht, 1966).

The VES survey, supported by geological information, is an essential tool in hydrogeological studies, as it allows the characterization of large extensions in a short time at reasonable costs. The high resistive contrast among the formations involved allows the unit limits to be clearly defined and the degree of pore water mineralization and layer thickness to be estimated (Sosa and Pala- 
zzo, 2000). VESs and hydrochemical data have been used to examine the degree of intrusion of salt water in aquifers (Edet and Okereke, 2001; Kouzana et al., 2010)

Archie (1942) found the following relation between the resistivities of brine saturated sand (Ro) and brine ( $\mathrm{Rw}$ ) when he studied oil on clean sands saturated by brine:

$$
F=\frac{R_{0}}{R_{w}},
$$

where $\mathrm{F}$ is the formation factor; Ro is the resistivity of the saturated formation; and Rw is the resistivity of the pore water. When the materials are not clean sands, the calculated formation factor is called the apparent formation-factor (Fa). Several authors (Norzagaray-Campos et al., 2002; Grellier et al., 2007; Peinado-Guevara et al., 2009) have successfully applied the Archie's relation to hydrogeology studies, including studies of rocks with silt and clay areas.

The Río Sinaloa Valley is a wide coastal plain whose subsoil shows freshwater and saltwater bodies. The region is formed by a landscape composed of a smooth relief closely related to the origin and nature of the rocks' formation. The oldest rocks composing the geological basement are made up of shales and cherts. Tuff and sandstone formations and stratified and cemented conglomerates overlie these rocks. The subsoil plain was formed by a large sediment accumulation, reaching thicknesses greater than 500 meters in the central valley and diminishing toward the Western Sierra Madre. The current delta plain is composed of gravel, sands, silt and clay deposited in deltas (CNA, 2002). The static aquifer water level in the area varies between 0.5 and $8 \mathrm{~m}$ (Figure 1).

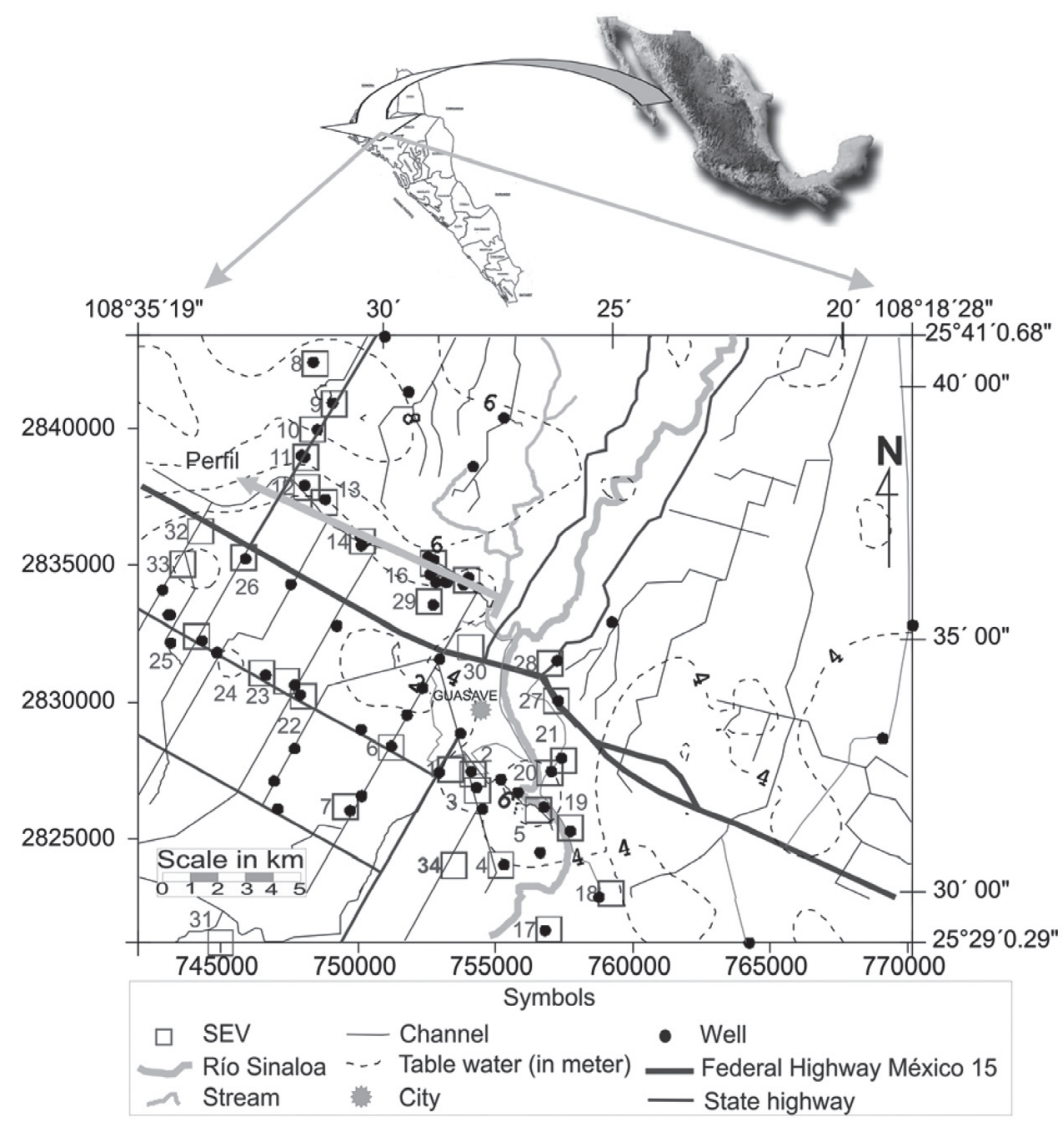

Figure 1. Location of the study area. 
This study aims to generate a tool for estimating the chloride concentration in the underground water of the Guasave region, Sinaloa, Mexico, using subsoil resistivity values obtainned from VES method, and the relation between the EC and the chloride concentration in the water based on the statistical analysis of the parameters obtained in wells.

\section{Materials and methods}

A total of 1,358 water well samples from different locations of the Guasave municipality were used to determine the $\mathrm{Cl}$ - and $\mathrm{EC}$ concentrations. From the total analyzed samples, 66 were collected and analyzed in October 2008, corresponding to wells for domestic use; 44 correspond to the western portion of the Sinaloa river and 12 to the eastern portion (Figure 1). Information regarding the 1,292 remaining samples (period 19802005) was provided by the Comisión Nacional del Agua. The geographic coordinates of each well were determined using a portable Garmin eTrex H GPS.

The chloride concentrations of the water samples were determined by silver nitrate tritation at the laboratory of the Departamento de Aguas Subterráneas from District 063 of the Comisión Nacional del Agua. The EC was determined in the field using a Hanna conductivity meter (model HI98130, Hanna Instruments, Instruction Manual HI 98129 and HI 98130. http://www.hannainst.es/catalogo/fichas/m_98129-98130.pdf). The water samples correspond to the aquifer formation, as they were obtained during the pumping of the wells.

Thirty-four VESs were conducted using the Schlumberger array with a maximum spacing of the current electrodes of $\mathrm{AB} / 2=50 \mathrm{~m}$ (Orellana, 1982). Twenty-nine of the VES arrays were placed near a well, contrasting the values of the subsoil resistivity with the characteristics of the aquifer water (electrical conductivity and chloride concentration). The five remaining VESs were performed at sites without wells to verify the applicability of the method.

The apparent resistivity (ra) versus the $\mathrm{AB} / 2$ function is obtained by implementing the device mentioned above. The subsoil resistivity can be obtained from field data; therefore, it is assumed that the subsoil is stratified in horizontal, homogeneous and isotropic layers in regard to the electrical resistivity (Orellana, 1982). In other words, the VESs allow readings of electrical currents and voltage differences in the field. These readings are transformed into apparent electrical resistivity values, providing the true electrical resistivity of the subsoil by inverse numeric modeling methods assuming the geological medium composed of horizontal, homogeneous and isotropic layers. The theoretical solution of this problem consists in solving the Laplace equation with boundary conditions. The data on apparent resistivity from each VES collected in the field were modeled with the program Resix-Plus version 1.31 (Advanced Geosciences, Inc, U.S.A., 1992), which was used to process the data by an algorithm based on the method of successive approximations or interactions until the best mathematical response or solution to the curve of the data of apparent resistivity was reached, by which the true subsoil resistivity was obtained. The resistivity (Ro) of saturated thickness is obtained by modeling the processing of VES and correlating it with pore water resistivity (Rw) by a linear function. Models of linear, polynomial and potential regression were used to relate the EC with the $\mathrm{Cl}^{-}$concentration.

Seven 4 m-deep drills were made to colect soil samples. The subsoil samples were extracted at different depths and were subject to a drying and homogenization process to determine their texture (silts, sands and clay content) by the Bouyoucos method. 


\section{Results and discussion}

The lateral and vertical variation of sediment can be observed from the profile traced in the study area. Figure 2 shows that the presence of clays in the featured section is relatively low compared with the concentrations of silt and sand; such material saturated with slightly brackish or brackish water satisfies the conditions for the application of Archie's Law.

As result of VES interpretation process, the resistivity and thickness values of the aquifer layer were obtained. Figure 1 shows the distribution of 34 VESs that were made on both sides of the Sinaloa River. The model obtained for VES 1 is illustrated in Figure 3 along with corresponding data of apparent resistivity. The first layer, with a 4.3-m thickness, corresponds to a silt-loam soil, and the second sandy layer, with a $11.7-\mathrm{m}$ thickness corresponds to the aquifer.

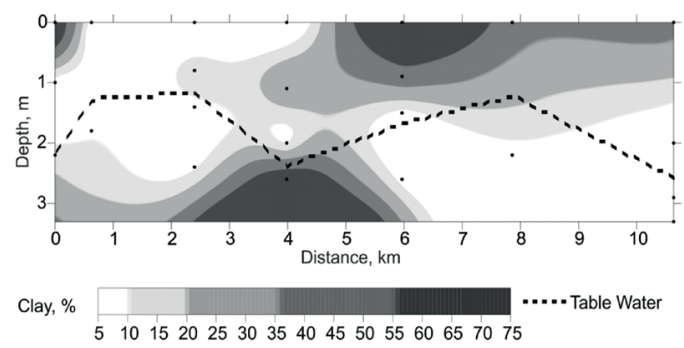

Figure 2. Clay content profile perpendicular to the Sinaloa River.

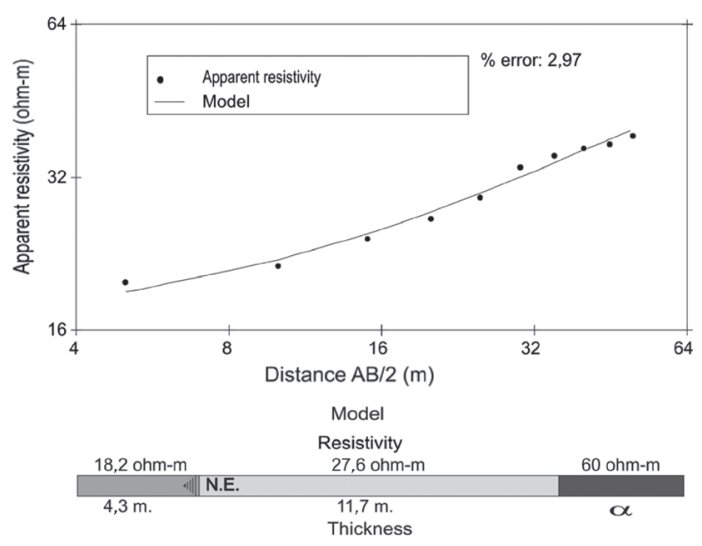

Figure 3. Vertical electrical sounding (VES) with the fitted model and the resulting lithological column.
Figure 4 shows the results obtained in the 29 parametric VESs and the analysis of the groundwater samples. Figure 4 shows a linear function directly proportional between the saturated layer resistivity (Ro) and the groundwater resistivity (Rw); as the pore water resistivity increases, the formation resistivity also increases. The value of the linear correlation coefficient ( $\mathrm{R}$ ) is higher than 0.9 , according to the following equation:

$\mathrm{RW}=0,427 \mathrm{Ro}+1,987$

The relationships between the chloride concentrations and electrical conductivity for the different regression models proposed are shown in Figure 5. The correlation coefficients obtained for the different fit types are presented in Table 1. In general, the linear model was more practical in its simplicity, showing a correlation coefficient very similar to the other models. The models fitted for the 1,358 underground water samples are the following:

Polynomial $[\mathrm{Cl}-]=0.008 \mathrm{EC} 2+8.87 \mathrm{EC}$

Linear

$[\mathrm{Cl}-]=9.222 \mathrm{EC}$

Potential

$[\mathrm{Cl}-]=7.35 \mathrm{EC} 1,062$

When the fit was made with only the 66 well water samples collected and analyzed in 2008, the relations were as follows:

$\begin{array}{ll}\text { Polynomial } & {[\mathrm{Cl}-]=-0.0785 \mathrm{EC} 2+5.288 \mathrm{EC}(5)} \\ \text { Linear } & {[\mathrm{Cl}-]=4.928 \mathrm{EC}} \\ \text { Potential } & {[\mathrm{Cl}-]=5.271 \mathrm{EC} 0,947}\end{array}$

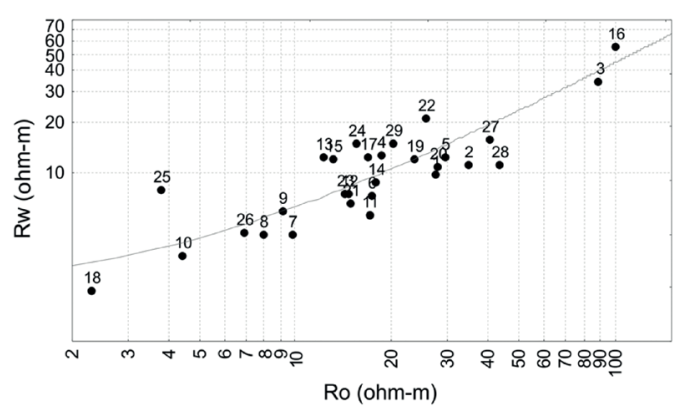

Figure 4. Relation between Ro and RW. 
Table 1. Correlation coefficients for the different models.

\begin{tabular}{|c|c|c|c|c|c|c|c|}
\hline \multirow{2}{*}{$\begin{array}{l}\text { Total } \\
\text { sample }\end{array}$} & \multicolumn{2}{|c|}{$\mathrm{EC}\left(\mathrm{dS} \mathrm{m} \mathrm{m}^{-1}\right)$} & \multicolumn{2}{|c|}{$\mathrm{Cl}-\left(\mathrm{meq} \mathrm{L}^{-1}\right)$} & \multicolumn{3}{|c|}{$\mathrm{R}$} \\
\hline & Maximum & Minimum & Maximum & Minimum & Polynomial & Linear & Potential \\
\hline 1358 & 95 & 0.15 & 900 & 0.5 & 0.965 & 0.965 & 0.967 \\
\hline 661 & 8.08 & 0.18 & 40 & 0.6 & 0.948 & 0.946 & 0.948 \\
\hline
\end{tabular}

${ }^{1}$ Samples taken in October 2008.
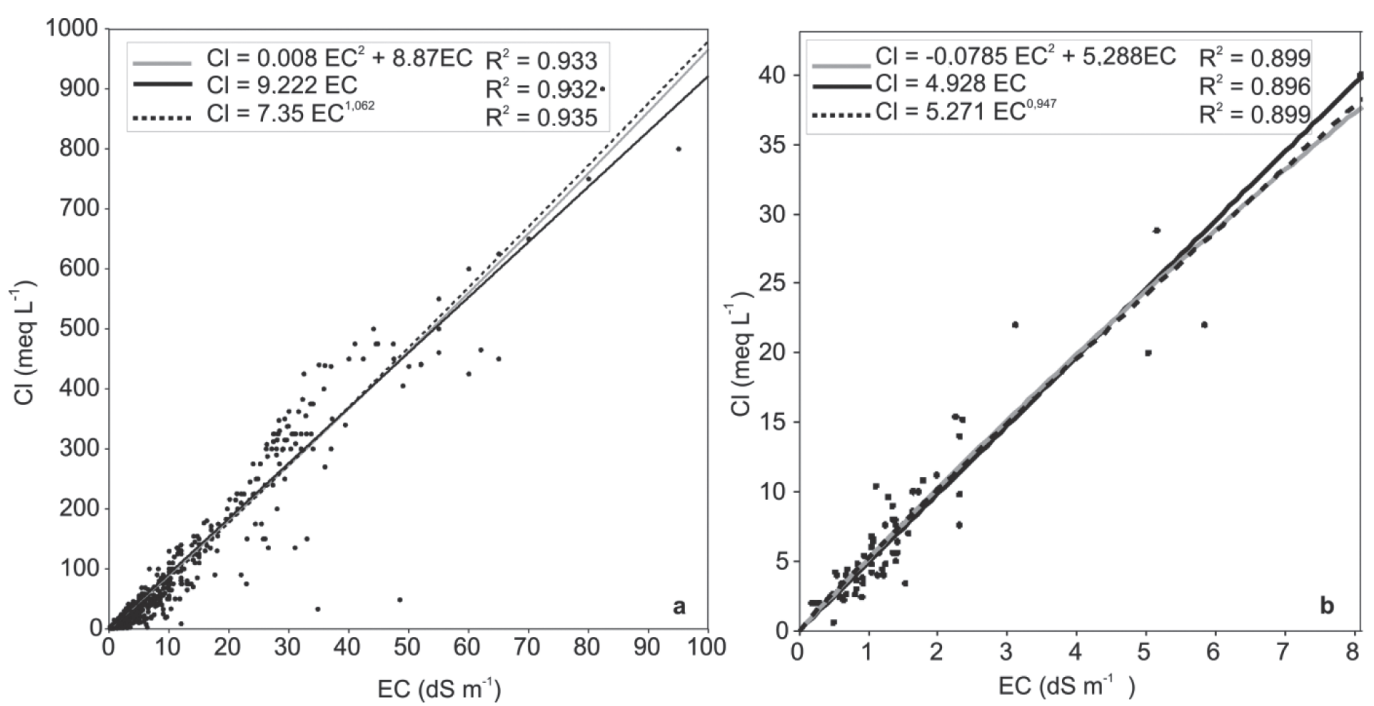

Figure 5. Water electrical conductivity vs chloride concentration. a) Fits for 1358 samples collected from 1980 to 2008 , b) Fits only for the 66 samples collected in 2008.

The 1358 analized samples correspond to the Guasave municipality, Sinaloa; therefore, the range corresponding to the values of the $\mathrm{EC}$ is wider, with values between $0.15 \mathrm{dS} \mathrm{m}^{-1}$ and 95 $\mathrm{dS} \mathrm{m} \mathrm{m}^{-1}$ and with a chloride concentration of 0.5 meq $\mathrm{L}^{-1}$ at 900 meq $\mathrm{L}^{-1}$. The relation obtained for the water samples analyzed in the 66 wells in October 2008 corresponds to the area under study, with values varying between 0.18 and 8.08 $\mathrm{dS} \mathrm{m}{ }^{-1}$ for the EC and $0.6 \mathrm{meq} \mathrm{L}^{-1}$ at $40 \mathrm{meq} \mathrm{L}^{-1}$ for the chloride concentration.

Finally, the water EC and chloride concentrations were calculated based on the results obtained from the five VESs (saturated thickness resistivity (Ro)) at the sites without drilling and using relations (5), (6) and (7). The Rw value was obtained using equation 1 and the water EC as the inverse of the Rw. Equation 6 was used to estimate the
Cl- concentration, which is the linear model, because it is a simple application. Because Rw and EC are inversely proportional, and by a unit conversion, the equation is:

$R w=\frac{10}{E C}$

The results obtained by applying equation (8) are presented in column 9 of Table 2, where the 29 VESs can be observed with the corresponding $\mathrm{Rw}, \mathrm{EC}$ and $\mathrm{Cl}^{-}$values and the corresponding values calculated from Ro.

The $\mathrm{Rw}$ and $\mathrm{Cl}^{-}$values determined by electrical measurements were correlated by the values determined in the field ( $\mathrm{Rw})$ and laboratory $\left(\mathrm{Cl}^{-}\right)$, showing a considerable dispersion in regard to the identity expected $\mathrm{Y}=\mathrm{X}$ (Figure 6). The correlation between the $\mathrm{Rw}$ and $\mathrm{Cl}^{-}$values measured and calculated is 
Table 2. Comparison between parameters Rw, EC and Cl- determined in the laboratory and calculated from measurements of electrical resistivity.

\begin{tabular}{|c|c|c|c|c|c|c|c|c|c|}
\hline \multirow[b]{2}{*}{ VES } & \multicolumn{2}{|c|}{ Coordinates } & \multirow[b]{2}{*}{$\begin{array}{c}\mathrm{RO} \\
\text { (ohm-m) }\end{array}$} & \multicolumn{3}{|c|}{ Measured } & \multicolumn{3}{|c|}{ Calculate } \\
\hline & East & North & & $\begin{array}{c}\mathrm{Rw} \\
\text { (ohm-m) }\end{array}$ & $\begin{array}{c}\mathrm{EC} \\
\left(\mathrm{dS} \mathrm{m}^{-1}\right) \\
\end{array}$ & $\begin{array}{c}\mathrm{Cl}^{-} \\
\left(\mathrm{meq} \mathrm{L}^{-1}\right)\end{array}$ & Rw (ohm-m) & $\begin{array}{c}\mathrm{EC} \\
\left(\mathrm{dS} \mathrm{m}^{-1}\right) \\
\end{array}$ & $\begin{array}{c}\mathrm{Cl}^{-} \\
\left(\mathrm{meq} \mathrm{L}^{-1}\right) \\
\end{array}$ \\
\hline 1 & 753371 & 2827530 & 27.6 & 9.7087 & 1.03 & 6.4 & 13.7722 & 0.7261 & 3.6 \\
\hline 2 & 754177 & 2827355 & 35 & 11.1111 & 0.9 & 2.4 & 16.932 & 0.5906 & 2.9 \\
\hline 3 & 754342 & 2826767 & 89 & 34.4828 & 0.29 & 2 & 39.99 & 0.2501 & 1.2 \\
\hline 4 & 755202 & 2824048 & 18.6 & 12.5 & 0.8 & 2.6 & 9.9292 & 1.0071 & 5 \\
\hline 5 & 756563 & 2826061 & 29.3 & 12.1951 & 0.82 & 3.6 & 14.4981 & 0.6897 & 3.4 \\
\hline 6 & 751213 & 2828331 & 17.3 & 7.1942 & 1.39 & 5 & 9.3741 & 1.0668 & 5.3 \\
\hline 7 & 749540 & 2826163 & 9.8 & 4.329 & 2.31 & 7.6 & 6.1716 & 1.6203 & 8 \\
\hline 8 & 748447 & 2842366 & 7.9 & 4.329 & 2.31 & 14 & 5.3603 & 1.8656 & 9.2 \\
\hline 9 & 749141 & 2840885 & 9.1 & 5.848 & 1.71 & 10 & 5.8727 & 1.7028 & 8.4 \\
\hline 10 & 748361 & 2839944 & 4.4 & 3.2051 & 3.12 & 22 & 3.8658 & 2.5868 & 12.7 \\
\hline 11 & 748098 & 2838923 & 17 & 5.618 & 1.78 & 10.8 & 9.246 & 1.0815 & 5.3 \\
\hline 12 & 748130 & 2837838 & 14.7 & 7.4627 & 1.34 & 9 & 8.2639 & 1.2101 & 6 \\
\hline 13 & 748780 & 2837301 & 12.2 & 12.3457 & 0.81 & 4 & 7.1964 & 1.3896 & 6.8 \\
\hline 14 & 750155 & 2835871 & 17.7 & 8.6957 & 1.15 & 5.6 & 9.5449 & 1.0477 & 5.2 \\
\hline 15 & 753959 & 2834461 & 13.1 & 11.9048 & 0.84 & 4.8 & 7.5807 & 1.3191 & 6.5 \\
\hline 16 & 752741 & 2835073 & 100 & 55.5556 & 0.18 & 2 & 44.687 & 0.2238 & 1.1 \\
\hline 17 & 756946 & 2821707 & 16.8 & 12.1951 & 0.82 & 3 & 9.1606 & 1.0916 & 5.4 \\
\hline 18 & 759204 & 2822998 & 2.3 & 1.992 & 5.02 & 20 & 2.9691 & 3.368 & 16.6 \\
\hline 19 & 757726 & 2825404 & 23.4 & 12.0482 & 0.83 & 3.6 & 11.9788 & 0.8348 & 4.1 \\
\hline 20 & 756976 & 2827402 & 27.8 & 10.8696 & 0.92 & 3.4 & 13.8576 & 0.7216 & 3.6 \\
\hline 21 & 757488 & 2827872 & 14.9 & 6.5359 & 1.53 & 3.4 & 8.3493 & 1.1977 & 5.9 \\
\hline 22 & 748010 & 2830201 & 25.6 & 20.8333 & 0.48 & 2.6 & 12.9182 & 0.7741 & 3.8 \\
\hline 23 & 747412 & 2830762 & 14.3 & 7.4074 & 1.35 & 8 & 8.0931 & 1.2356 & 6.1 \\
\hline 24 & 746509 & 2831053 & 15.5 & 14.9254 & 0.67 & 4 & 8.6055 & 1.162 & 5.7 \\
\hline 25 & 744133 & 2832380 & 3.8 & 7.8125 & 1.28 & 9.6 & 3.6096 & 2.7704 & 13.7 \\
\hline 26 & 745854 & 2835272 & 6.9 & 4.4444 & 2.25 & 15.4 & 4.9333 & 2.027 & 10 \\
\hline 27 & 757217 & 2830041 & 40.4 & 15.625 & 0.64 & 2.2 & 19.2378 & 0.5198 & 2.6 \\
\hline 28 & 756999 & 2831404 & 43.6 & 11.236 & 0.89 & 3.4 & 20.6042 & 0.4853 & 2.4 \\
\hline 29 & 752596 & 2833660 & 20.1 & 14.7059 & 0.68 & 2.6 & 10.5697 & 0.9461 & 4.7 \\
\hline
\end{tabular}

observed in Figure 6. The location of sites with VES points without drilling is shown in Table 3, which helped to determine the Ro value, which was used as a reference to determine the $\mathrm{Rw}, \mathrm{EC}$ and $\mathrm{Cl}^{-}$.

The effect of salinity and the chloride concentration on usable water in cultivation was analyzed, according to Palacios et al. (1997). The degrees of restriction for irrigation water are observed in Figure 7; with a higher effect in both parameters of the East side of the Sinaloa River. In regard to the ion chloride concentration and the groundwater electrical conductivity, the water quality to the east side of Sinaloa river is more saline, 
Table 3. Rw values (obtained from resistivity of saturated depth), electrical conductivity and chloride concentrations.

\begin{tabular}{lcccccc}
\hline \multirow{2}{*}{ VES } & \multicolumn{2}{c}{ Coordinates } & \multirow{2}{*}{$\begin{array}{c}\text { Ro } \\
\text { (ohm-m) }\end{array}$} & $\begin{array}{c}\mathrm{Rw} \\
(\mathrm{ohm}-\mathrm{m}) \\
\text { Ec. } 1\end{array}$ & $\begin{array}{c}\mathrm{EC} \\
\left(\mathrm{dS} \mathrm{m} \mathrm{m}^{-1}\right)\end{array}$ & $\begin{array}{c}{\left[\mathrm{Cl}^{-}\right]} \\
\left(\mathrm{meq} \mathrm{L}^{-1}\right)\end{array}$ \\
\hline 30 & East & North & & Ec. 6 \\
31 & 754098 & 2831998 & 16 & 8.82 & 1.13 & 5.59 \\
32 & 744999 & 2821205 & 9.4 & 6.00 & 1.67 & 8.21 \\
33 & 744265 & 2836239 & 7.8 & 5.31 & 1.88 & 9.27 \\
34 & 743629 & 2835038 & 9.87 & 6.20 & 1.61 & 7.95 \\
\hline
\end{tabular}
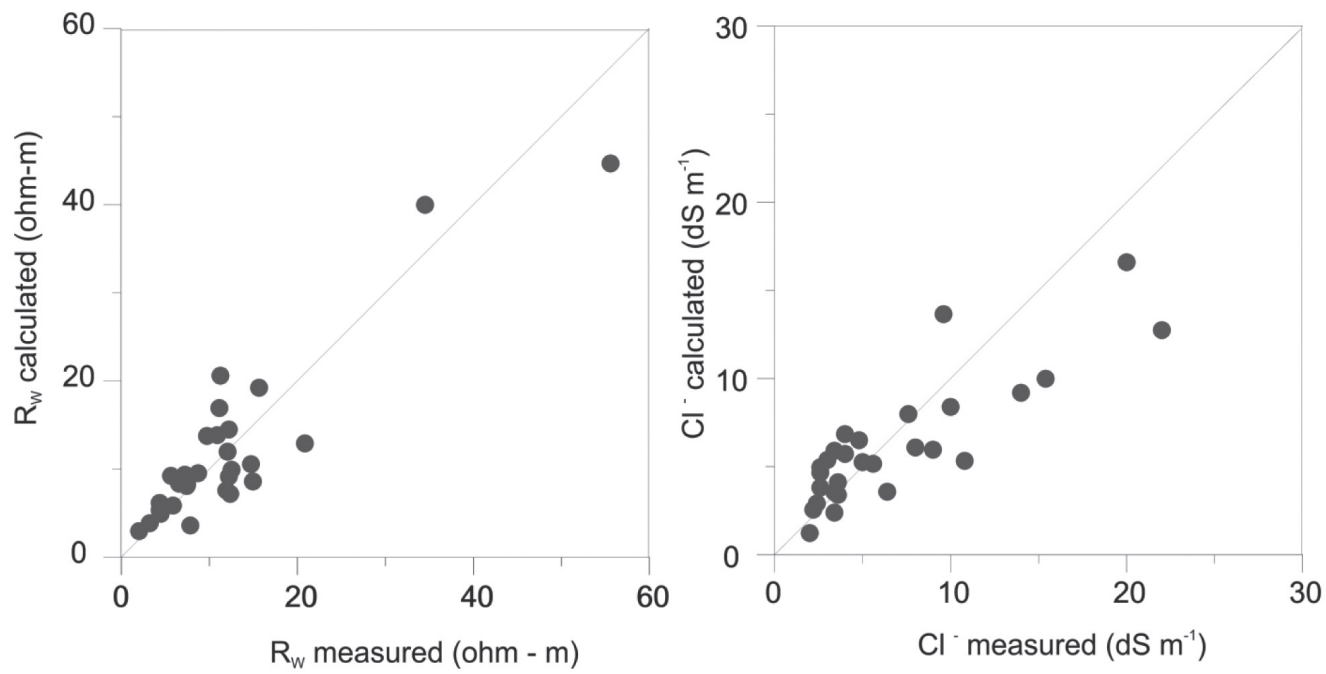

Figure 6. Correlation between measured and calculated values of Rw and Cl-.

with chloride concentrations higher than to the west, which is an indicator for new drill planning considering the use of water, as well as the vulnerability of zones near the portions considered as water for irrigation, because overexploitation of water may increase the contaminated area.

The linear regression model between the groundwater electrical conductivity and the chloride concentrations proposed in this work for the 1358 samples is very similar to the results by Abyaneh et al. (2005): $\left[\mathrm{Cl}^{-}\right]=9 \mathrm{EC}$ for $0.15<\mathrm{EC}<39.9 \mathrm{dS} \mathrm{m}^{-1}$. The relation in this work is $\left[\mathrm{Cl}^{-}\right]=9.22 \mathrm{EC}$, for $0.15<\mathrm{EC}<95$ $\mathrm{dS} \mathrm{m}-1$. On the other hand, the linear model $\left[\mathrm{Cl}^{-}\right]$ $=4.928 \mathrm{EC}$, for $0.18<\mathrm{EC}<8.08 \mathrm{dS} \mathrm{m}^{-1}$, for the 66 samples corresponding to the area under study and collected in 2008, is also similar to the linear model proposed by Hajrasuliha et al. (1991): $\left[\mathrm{Cl}^{-}\right]$ $=5.22 \mathrm{EC}$, for $\mathrm{EC}=16 \mathrm{dS} \mathrm{m}^{-1}$. The different models presented, where the water electrical conductivity was related to the chloride concentration, show good fit for the linear, polynomial, and potential models, with $\mathrm{R}$ fit values higher than 0.94 . Consequently, an approximation of the chloride concentration is possible with only the groundwater EC value. The gradient of the linear model for the relation $\left[\mathrm{Cl}^{-}\right]$ against $\mathrm{EC}$ shows that the gradient tends to increase as the chloride concentration increases (Figure 5).

Finally, this work presents a rapid, reliable, and economical technique to estimate the concentration of chloride ions and the water EC, regardless of drilling location around Guasave. Therefore, application of this method may result in more successful drilling in search of fresh water.

\section{Acknowledgments}

To Comisión Nacional del Agua and Instituto de Geología of UNAM, for providing help for this work. 


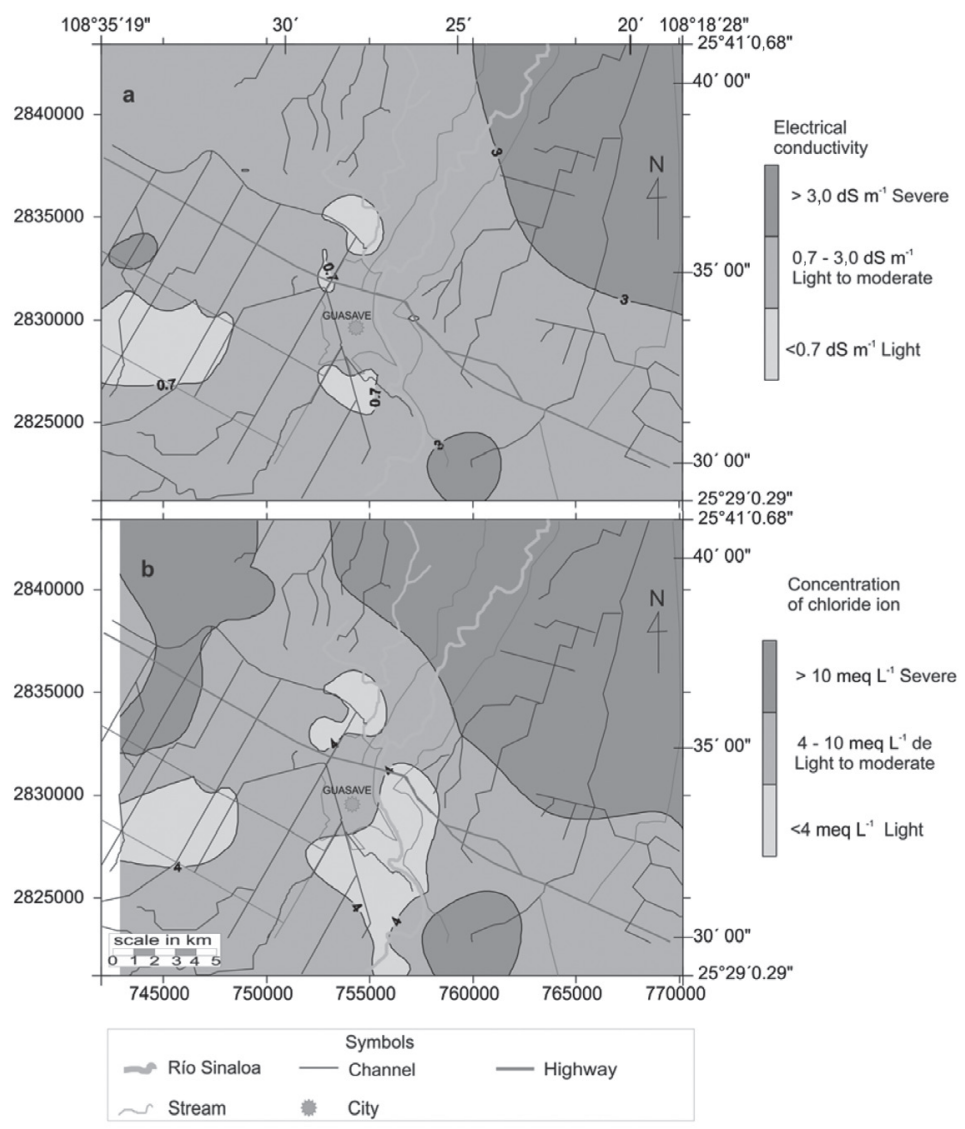

Figure 7. Water restriction degree for agriculture according to (a) electrical conductivity and (b) concentration of chloride ion.

\section{Resumen}

H. Peinado-Guevara, C. Green-Ruíz, J. Herrera-Barrientos, O. Escolero-Fuentes, O. Delgado-Rodríguez, S. Belmonte-Jiménez y M. Ladrón de Guevara. 2012. Relación entre concentración de cloruros y conductividad eléctrica en aguas subterráneas y su estimación a partir de Sondeos Eléctricos Verticales (SEV) en Guasave, Sinaloa, México. Cien. Inv. Agr. 39(1): 229-239. Los suelos de zonas de clima árido o semiárido a menudo tienen problemas de salinidad, por lo que la calidad del agua para riego juega un papel importante en la producción agrícola. Los análisis en agua subterránea incluyen la determinación del ión cloruro, el cual en grandes concentraciones es tóxico para las plantas. Se analizaron en laboratorio 1358 muestras de agua subterránea tomadas en el periodo de 1980 - 2008 con lo que se determinó la conductividad eléctrica y la concentración del ión cloruro. Estos resultados sirvieron para obtener la ecuación de correlación lineal $\left[\mathrm{Cl}^{-}\right]=4.928 \mathrm{EC}(\mathrm{R}>0.94)$, con el propósito de estimar la concentración del ión cloruro en función de la conductividad eléctrica del agua en el área de estudio. Se realizó la prospección geofísica a través de 34 Sondeos Eléctricos Verticales (SEV), para calcular la conductividad eléctrica del agua a partir de la interpretación de los datos de resistividad aparente. Con $29 \mathrm{SEV}$ se relacionó la resistividad del medio saturado con la resistividad del agua subterránea mediante la ecuación lineal: $\mathrm{Rw}=0.427 \mathrm{Ro}+1.987$ Posteriormente, se calculó la conductividad eléctrica del agua, como inversa de su resistividad, 
por último, la concentración del ión cloruro mediante la ecuación expuesta anteriormente para el área de estudio. Siguiendo el mismo procedimiento, en los cinco SEV restantes efectuados en lugares donde no hay perforaciones, se pudo estimar la resistividad eléctrica de la capa saturada (Ro), la resistividad eléctrica del agua del acuífero (Rw, y su inverso EC) y la concentración del ión cloruro, sin requerir el uso de una técnica destructiva.

Palabras clave: Cloruros, conductividad eléctrica, Ley de Archie, resistividad, sondeo eléctrico vertical (SEV).

\section{References}

Abyaneh, H. Z., A. H. Nazemi, M. R. Neyshabori, K. Mohammadi, and G.H. Majzoobi. 2005. Chloride estimation in ground water from electrical conductivity measurement. Tarim Bilimleri Dergisi 11: 110-114.

Aceves, N.E. 1979. El ensalitramiento de los suelos bajo riego: identificación, control, combate y adaptación. Chapingo: Escuela Nacional de Agricultura, Colegio de Postgraduados, Chapingo, México. 382 pp.

Alhumoud, J.M., F.M. Al-Ruwaih, and Z.M. AlDhafeeri. 2010. Groundwater quality analysis of limestone aquifer of Al-Sulaibiya field, Kuwait. Desalination 254: 58-67.

Archie, G.E. 1942. The electrical resistivity log as an aid in determining some reservoir characteristics. Trans. AIMME 146: 54-62.

CNA. 2002. Determinación de la disponibilidad de agua en el acuífero Río Sinaloa. Comisión Nacional del Agua (CNA). México, D.F. México. $36 \mathrm{pp}$.

Crovetto, L.C. 1999. Agricultura de Conservación. Colección Vida Rural. Editorial Eumedia. Madrid, España. 316 pp.

Edet, A., and C. Okereke. 2001. A regional study of saltwater intrusion in southeastern Nigeria based on the analysis of geoelectrical and hydrochemical data. Environmental Geology 40 (10): 12781289.

Grellier, S., K. R. Reddy, J. Gangathulasi, R. Adib, and C.C. Peters. 2007. Correlation between electrical resistivity and moisture content of municipal solid wasted in bioreactor landfill. Geotechnical Special Publication 163: 1-14.
Hajrasuliha, S., D.K. Cassel, and Y. Rezainejad. 1991. Estimation of chloride ion concentration in saline soils from measurement of electical conductivity of saturated soil extracts. Geoderma 49: 117-127.

Keller, G. V., and F. Frischknecht. 1966. Electrical Methods in Geophysical Prospecting. Oxford Pergamon Press, USA. 517 pp.

Kouzana, L., R. Benassi, A. Ben Mammou, and M. Sfar felfoul. 2010. Geophysical and hydrochemical study of the seawater intrusion in Mediterranean semi arid zones. Case of the Korba coastal aquifer (Cap-Bon, Tunisia). Journal of African Earth Sciences 58: 242-254.

McNeil, V.H., and M.E Cox. 2000. Relationship between conductivity and analysed composition in a large set of natural surface-water samples, Queensland, Australia. Environmental Geology 39: 1325-1333.

Norzagaray-Campos, M., J. Herrera-Barrientos, F. Herrera-Barrientos, P. Muñoz-Sevilla, E. YuriMendoza, and L. Capurro-Filigrasso. 2002. Simulación bidimensional del transporte de solutos en la costa del acuífero Santo Domingo, Ensenada; B. C. México. Rev. Geol. America Central 27: 153-162.

Orellana, E. 1982. Prospección geoeléctrica en corriente continua. Segunda Edición, Ed. Paraninfo, Madrid, España. 578 pp.

Oteri, A.U. 1988. Electric log interpretation for the evaluation of salt water intrusion in the eastern Niger Delta. Hydrological Sciences Journal 1:19-30.

Palacios, V., E.J. Chávez, and L. Tijerina. 1997. Requerimientos de agua para riego. In: Requerimientos de agua para riego del Manual 
Nacional de Ingeniería del Servicio de Conservación de Suelos. Departamento de Agricultura de los Estados Unidos de América. Comisión Nacional del Agua. Edo de México, México. $405 \mathrm{pp}$.

Peinado-Guevara, H., J. Herrera-Barrientos, and M. Ladrón de Guevara. 2009. Determinación de la conductividad hidráulica mediante medidas de resistividad eléctrica. Ingeniería Hidráulica en México XXIV (4): 123-134.

Reluy, F.V., J.M. de Paz-Bécares, R.D. Zapata, and J. Sánchez. 2004. Development of an equation to relate electrical conductivity to soil and water salinity in a Mediterranean agricultural environment. Aust. J. Soil Res 42: 381-388.

Richards, L.A. 1954. Diagnóstico y rehabilitación de suelos salinos y sódicos. Manual 60. Personal del
Laboratorio de Salinidad de los Estados Unidos de América. Departamento de Agricultura de los E.U.A., edit. LIMUSA. México. D.F. 172 pp.

Sosa, D., and R. Palazzo. 2000. Los estudios de prospección geoeléctrica por corriente continua en la llanura argentina. In: A. Olmo and J.A. López-Geta (eds.). Actualidad de las técnicas geofísicas aplicadas en hidrogeología. IGME, Madrid, España. p. 133 - 139.

WHO. 2003. Chloride in drinking-water. Background document for preparation of WHO Guidelines for drinking-water quality. Geneva, World Health Organization (WHO/SDE/WSH/03.04/3). 9 pp.

Xu, M., and Y. Eckstain. 1997. Statistical analysis of the relationships between dispersivity and other physical properties of porous media. Hydrogeology Journal 5: 4-20. 
